\title{
THE CONCEPT AND APPLICATION OF HIBAH AS A FINANCIAL INSTRUMENT FROM THE MALAYSIAN LEGAL PERSPECTIVE: AN ANALYSIS
}

\author{
Rusni Hassan* \\ Nor Azdilah Mohamad Zaizi**
}

\begin{abstract}
The principle of hibah (gift) is a popular subject in the Islamic law of administration, relating to wealth management. Hibah is a solution to deliver wealth to non-heirs apart from the wasiyyah (bequest) or faraid (succession) systems. However, in the broader context of wealth management in Malaysia, hibah has also been used as a financial instrument in the Islamic financial institutions' products and services. Based on that, the legality and enforcement of hibah with regards to the related applicable laws in the Malaysian legal system might be affected in two different situations. First, the conflict of jurisdiction may be arising from the fact that the matter of the classical hibah concept will be under the jurisdiction of the classical hibah concept will be under the jurisdiction of the States, whilst the commercial hibah which has been structured with the Islamic banking and takaful products and services established by the Islamic financial institutions, will be under the Federal government. The scarcity of literatures discussing hibah from the perspective of Islamic banking and finance contributes to the limited understanding and awareness among the society on this matter. In view of that, this study explores and analyse the concept and application of hibah as the financial instrument in the Islamic banking and takaful products and services. This study also analyzes some relevant Shari'ah and legal issues on the application of hibah in the Islamic banking and takaful products and services, which are currently practiced by the Malaysian Islamic financial institutions. This is done by assessing relevant statutes and decided cases. This article finally provides
\end{abstract}

* Professor, Institute of Islamic Banking and Finance, International Islamic University Malaysia. Email: hrusni@iium.edu.my.

** Postgraduate student, Master of Science (Islamic Banking and Finance), Institute of Islamic Banking and Finance (IIBBF), International Islamic University Malaysia. Email: azdilahibf@gmail.com.

[Received: 23 October 2019, Accepted: 5 April 2020, Published: 30 June 2020] 
recommendations to improve and enhance the application of hibah as an Islamic banking and takaful products and services in Malaysia.

Keywords: hibah, gift, Islamic financial institutions, Islamic financial instrument, legal

\title{
MEMAHAMI KONSEP DAN PENGGUNAAN HIBAH SEBAGAI SUATU INSTRUMEN KEWANGAN DARI PERSPEKTIF UNDANG-UNDANG MALAYSIA
}

\begin{abstract}
ABSTRAK
Prinsip hibah atau hadiah adalah biasanya digunapakai di dalam sistem undang-undang pentadbiran bagi para Muslimin di Malaysia, terutamanya apabila melibatkan pengurusan harta benda. Hibah di dalam undang-undang pentadbiran Islam telah digunapakai sebagai suatu penyelesaian kepada pemberian harta benda kepada bukan waris selain daripada sistem wasiat atau faraid. Walaubagaimanapun, dalam konteks pengurusan harta yang lebih meluas di Malaysia, hibah kini turut digunapakai sebagai suatu instrumen kewangan oleh institusi kewangan Islam di dalam sesetengah produk dan perkhidmatan yang ditawarkan oleh mereka. Oleh yang demikian, keesahan dan penguatkuasaan undang-undang Malaysia yang harus digunapakai terhadap dua jenis hibah sebegini akan memberi kesan apabila ia melibatkan dua situasi berbeza. Konflik undang-undang boleh berlaku atas sebab hibah klasik (hibah umum) berada di bawah bidang kuasa undang-undang negeri, manakala hibah berbentuk komersial yang dibentuk bersama-sama dengan produk perbankan Islam dan perkhidmatan takaful oleh institusi kewangan Islam pula berada di bawah bidang kuasa pusat (negara). Kekurangan kajian literatur yang membincangkan hibah dari perspektif perbankan dan kewangan Islam menyumbang kepada pemahaman dan kesedaran yang terhad di kalangan masyarakat umum kepada hibah jenis ini. Justeru, makalah ini berhasrat untuk meneroka dan menganalisis konsep dan penggunaan hibah sebagai instrumen kewangan di dalam produk perbankan dan perkhidmatan kewangan Islam. Makalah ini turut mengkaji dan menganalisis isu Shari'ah dan undang-undang berkaitan dengan penggunaan hibah di dalam produk perbankan dan perkhidmatan kewangan Islam yang kini digunapakai oleh institusi kewangan Malaysia, dengan merujuk kepada statut dan kes-kes mahkamah yang berkaitan. Pada pengakhiran makalah ini, penulis mengemukakan beberapa cadangan yang difikirkan munasabah untuk menambah baik dan meningkatkan potensi penggunaan hibah sebagai instrumen
\end{abstract}


kewangan di dalam produk dan perkhidmatan perbankan Islam dan takaful.

Kata kunci: hibah, hadiah, institusi kewangan Islam, instrumen kewangan Islam, undang-undang

\section{INTRODUCTION}

Hibah is one of the important instruments used in Islamic wealth management. Hibah occurs where an individual confers his valuable asset to another, during his lifetime unilaterally, without any due consideration. Hibah in its original form is considered as a tabarru' contract, which is made without any reverse intention. In Islam, the practice of giving the hibah is encouraged among the Muslims as it promotes the concept of maqasid of Shari'ah in term of the protection of the wealth as well as strengthening the relationship with one another. In Malaysia, the hibah instrument is usually used by Muslims in planning asset distribution to the intended beneficiaries in relation to specific assets, whereby the ownership of the asset is transferred to the beneficiary during the donor's lifetime (inter vivos) or in certain limited circumstances, conditionally passed over after the donor's death.

In the context of modern practice in Malaysia, the application of hibah has been extended as a type of supporting financial instrument within the main Islamic financial services offered by some Islamic financial institutions. This type of hibah is considered as commercial hibah which is attached to other types of main Shari'ah-based contracts of product or services such as the contract of sale and purchase (albay'), lease (al-ijarah), kafalah (al-rahn), company (-al-syarikah), profit and loss sharing (al-mudharabah) and saving (al-wadiah) including takaful product. The act of giving hibah by the Islamic financial institutions to its customer is executed in the form of incentive, dividend or consolation for the purpose of motivating its customers to keep depositing their money in the Islamic banking account. This practice however, is unilaterally given by the respective Islamic banks itself on a discretionary basis and must not be interest based, unlike benefit offered under the conventional accounts.

To ensure that the Islamic financial institutions' application of hibah are in accordance with the Shari'ah principle, the specific reference on the application of hibah as financial instrument has been 
issued by Bank Negara Malaysia which is effective since $31^{\text {st }}$ July $2018 .^{1}$

Accordingly, by looking at the modern practice of hibah adopted by large number of Islamic financial institutions nowadays, this study intends to explore and examine to what extent the application of hibah as a financial instrument is compatible with the existing civil and Sha'riah laws in Malaysia.

\section{A LEGAL PERSPECTIVE OF THE PRACTICE OF HIBAH IN MALAYSIA}

Malaysia has permitted the practice of hibah into two (2) ways; firstly, for the assets' wealth management and secondly for the Islamic banking products and services as a supporting financial instrument. With regards to the first application, hibah has long been applied and recognized as a means to distribute a Muslim's asset after his death. The case of Kiah vs $\mathrm{Som}^{2}$ was found to be the first case that recorded the application of hibah in the 1950's ' ${ }^{3}$. In this case, the issue of hibah was raised by the disputed party in relation to the distribution of Muslim Malays' asset among the blood relationship such as between father and son, husband and wife, grandfather and grandson and so forth ${ }^{4}$. In reality, there are many court cases disputing the validity of hibah between family members which is also referred to as classical hibah. It is observed that the application of hibah was merely a form of distributing the assets between the family members, and that was made

1 Bank Negara Malaysia issued Hibah Policy Document which comprises of salient features and essential conditions of hibah as well as the regulatory, supervisory and operational requirements to be complied with by the Islamic financial institutions.

2 [1953] 19 MLJ 82.

3 Wan Kamal Mujani, Wan Mohd Hirwani Wan Hussain, Noor Inayah Yaakub, Rusnadewi Abdul Rashid, The Concept of Law of Gift Inter Vivos Under Islamic Law and the Contracts Act, 1950, International Business Management 5 (6), 2011, pp 319-325.

4 Wan Kamal Mujani, Wan Mohd Hirwani Wan Hussain, Noor Inayah Yaakub, Rusnadewi Abdul Rashid, "The Concept of Law of Gift Inter Vivos Under Islamic Law and the Contracts Act, 1950", International Business Management 5 (6), 2011, pp 319-325. See also the case of Tengku Jaafar vs State of Pahang [1987] 2, MLJ 74. 
in accordance with the Muslim law of administration which falls under Item 1, List II (State list) in the Ninth Schedule of the Federal Constitution. This provision provides the jurisdiction and power to the Shari'ah Court in each of Malaysia's states to handle the matter prescribed under the State list, and that includes the classical hibah practice. To date, the classical hibah is still not governed by any specific standard to be referred to by the Shari'ah Court 5 .

The second type of hibah can be referred to as the modern concept of hibah and it is applied as an Islamic financial supporting instrument for the Islamic banking and takaful products and services as offered by Islamic financial institutions. The hibah is also known as commercial hibah, due to its function and purpose as a financial instrument in the Islamic financial system. Being a financial instrument, it is therefore under the purview of the federal law as the Islamic financial institutions are governed under Item 1, List I (Federal List) in the Ninth Schedule of the Federal Constitution.

In general, the practice of hibah as a financial instrument has been permitted by the Shari'ah Advisory Council of Bank Negara Malaysia (SAC-BNM) by virtue of the Bank Negara Malaysia policy document on Hibah which comes into effect on $31^{\text {st }}$ July 2018. In pursuant to the policy, the act of giving hibah is always subject to the Islamic financial institution's own discretion, but must be based on strict conditions specified by Sha',riah requirements.

Currently, it is observed that A hibah can be applied together with other contracts which are being offered at the banking and financial institutions such as the contract of sale and purchase (al-bay'), lease (al-ijarah), kafalah (al-rahn), company (-al-syarikah), loan (qard') and saving (al-wadiah $)^{6}$.

5 Muda, Mohd Zamro,2008. "Instruments of Hibah and Wills: Analysis of the Regulations and Applications in Malaysia." Hibah and Faraid National Convention 2008 , $1-42$

http://www.islam.gov.my/sites/default/files/instruments _of_hibah_and_wills.pdf.

6 Abdul Halim El-Muhammady, Buku /Book of Undang-undang Muamalat dan Aplikasinya Kepada Produk-produk Perbankan Islam, Selangor: Aras Mega Sdn Bhd, 2006, ISBN: 9789839978148, Brand : Local Publisher, 1322. 
Aside from that, the hibah instrument has also been used in the takaful industry in two (2) ways: either by way of direct hibah or conditional hibah. In a direct hibah, the takaful company will structure and offer a takaful product to its takaful participants whereby the takaful benefits will be surrendered to the hibah recipient upon the maturity of the takaful certificate. Under this concept of hibah, the beneficiary of the takaful benefits may be the children of the takaful participant, or the takaful participant himself or herself. This concept of direct hibah covers the educational plan, medical plan and other types of plans offered by the takaful company. This is addition to the saving plan on behalf of the beneficiary himself/herself. As far as the direct hibah concept is concerned, this practice is allowed by all Muslim jurists.

On the other hand, the conditional hibah in takaful is made in respect of the nomination of the takaful recipient by the takaful participant during his life as to who will receive the takaful benefits as an executor of his estate or as the actual beneficiary. This kind of hibah is enforced subject to the occurrence of the event, i.e. the death of the takaful participant's death prior to the maturity of the takaful certificate. The practice of giving the conditional hibah in takaful is seen to be benefiting the beneficiary since all the payment sum or the benefits received can be directly given to the heirs of the deceased takaful participant without going through the faraid (Muslim law of administration) procedures ${ }^{7}$. It is important to note that however, the practice of giving the conditional hibah in takaful is taking the conditional elements in hibah ruqba i.e. the transfer of ownership of hibah benefit or asset can only be materialized upon the death of donating party in the contract. According to the majority of Muslim jurists, the condition imposed is considered as void even though the aqad entered is valid. Even so, the SAC-BNM resolution was made based on the minority opinion i.e. the Maliki jurists' opinion, in which they have permitted the validity of the conditions in hibah Ruqba ${ }^{8}$.

7 Muhamad, Nasrul Hisyam Nor. "Pemakaian Prinsip Hibah Dalam Sistem Kewangan Islam Di Malaysia: Tumpuan Kepada Industri Perbankan Islam dan Takaful"Jurnal Teknologi (Sains Sosial) 52, No. 1 (January 2010): pp 69-81, https://doi.org/10.11113/jt.v52.138.

8 Muhamad, Nasrul Hisyam Nor. "Pemakaian Prinsip Hibah Dalam Sistem Kewangan Islam Di Malaysia: Tumpuan Kepada Industri Perbankan Islam 
In addition to the above, pursuant to Section 142, Schedule 10, Para 3(2) of the Islamic Financial Services Act ("IFSA"), the conditional hibah provided under the takaful product is statutorily covered in Malaysia, whereby it has been structured to enforce the conditional hibah contract in the takaful product applicable only for Family Takaful Certificate and Personal Accident Takaful Certificate. The provision is made in relation to the SAC-BNM Resolution held on $21^{\text {st }}$ April 2003 on the permissibility of the conditional hibah in takaful business 9 . It is significant to note that prior to the IFSA enforcement, all matters pertaining to takaful products and services were governed under the Takaful Act 1984. Under the repealed Act, there was no such comprehensive provisions regarding the takaful nomination.

\section{SHARI'AH AND LEGAL ISSUES IN THE APPLICATION OF HIBAH AS A FINANCIAL INSTRUMENT}

There are several legal issues that arise in the application of hibah as a financial instrument in Malaysia. Among them are the conflict of jurisdiction between the Shari'ah and Civil courts, the uncertainty of terms between hibah and 'gift', the giving of conditional hibah in takaful nominations, the contract of hibah in the context of Section 26 of the Contract Act 1950 and the hybrid contract of hibah and trust as a financial instrument. These issues will be discussed in further detail in this part of the article, according to the sequence mentioned above.

\section{THE CONFLICT OF JURISDICTION BETWEEN THE SHARI'AH AND CIVIL COURTS}

The conflict of jurisdiction between Shari'ah Court and Civil Court among the most evident when dealing with hibah matters. This is especially so in cases where the nomination is made by Muslims under administrative law. This is due to the fact that the Malaysian Federal

dan Takaful"Jurnal Teknologi (Sains Sosial) 52,No. 1 (January 2010): pp 69-81, https://doi.org/10.11113/jt.v52.138.

9 Prof. Dr. Younes Soualhi, Saba' Radwan, Ibrahem Musa Tijani, "Nomination in the Context of IFSA 2013: A Critical Shariah Appraisal,", International Shariah Research Academy for Islamic Finance (ISRA) (2017), Issue No. 98/2017, pp 1-28. 
Constitution has provided two (2) separate jurisdictions for courts in matters pertaining to Islamic law and civil law. For the disputes pertaining to the commercial law of transaction, such as finance related banking products - including matters related to hibah contract, it will be contested in civil court. Meanwhile, matters pertaining to Islamic law, particularly personal and family matters, it falls within the purview of the Shari'ah Court. Aside from that, the issue of the grant of probate and letter of administration is also within the purview of civil court and this may cause a jurisdictional issue when the parties involved are professing different religion or may involve a corporation and not and individual.

In order to address the matter, there is a need to examine three types of provisions that are applicable in determining the jurisdictional issue that may arise in an award of hibah. The first provision that need to be examined is the provision regarding the scope of Shari'ah Court Jurisdiction

Article 74 of Item 1, List II of the State List in the Ninth Schedule of the Federal Constitution provides: -

1. Except with respect to the Federal territories of Kuala Lumpur, Labuan and Putrajaya, Islamic law and personal and family law of persons professing the religion of Islam, including the Islamic law relating to succession, testate and intestate, betrothal, marriage, divorce, dower, maintenance, adoption, legitimacy, guardianship, gifts, partitions and non-charitable trusts; wakafs and the definition and regulation of charitable and religious trusts, the appointment of trustees and the incorporation of persons in respect of Islamic religious and charitable endowments, institutions, trusts, charities and charitable institutions operating wholly within the State; Malay customs; Zakat, Fitrah and baitulmal or similar Islamic religious revenue; mosques or any Islamic public place of worship, creation and punishment of offences by persons professing the religion of Islam against precepts of that religion, except in regard to matters included in the Federal List; the constitution, organization and procedure of Syariah courts, which shall have jurisdiction only over persons professing the religion of Islam and in respect only of any of the matters included in this paragraph, but shall not have jurisdiction in respect of offences except in so far as conferred by federal law; the control of propagating doctrines and beliefs among persons professing the religion of Islam; the determination of matters of Islamic law and doctrine and Malay custom. 


\section{Provision regarding the scope of Civil Court Jurisdiction}

The provision under Article 74, 77 of Item 4, List I of the Federal List in the Ninth Schedule of Federal Constitution which mentions: -

4. Civil and criminal law and procedure and the administration of justice,

(a) constitution and organization of all courts other than Syariah Courts; including-

(b) jurisdiction and powers of all such courts;

(c) remuneration and other privileges of the judges and officers presiding over such courts;

(d) persons entitled to practise before such courts;

(e) subject to paragraph (ii), the following:

(i) contract; partnership, agency and other special contracts; master and servant; inns and inn-keepers; actionable wrongs; property and its transfer and hypothecation, except land; bona vacantia; equity and trusts; marriage, divorce and legitimacy; married women's property and status; interpretation of federal law; negotiable instruments; statutory declarations; arbitration; mercantile law; registration of businesses and business names; age of majority; infants and minors; adoption; succession, testate and intestate; probate and letters of administration; bankruptcy and insolvency; oaths and affirmations; limitation; reciprocal enforcement of judgments and orders; the law of evidence;

(ii) the matters mentioned in paragraph (i) do not include Islamic personal law relating to marriage, divorce, guardianship, maintenance, adoption, legitimacy, family law, gifts or succession, testate and intestate;

(A) Provision regarding the Interpretation of Finance under the Federal List /Civil Court Jurisdiction

The provision under Article 74, 77 of Item 7, List I- Federal List of the Ninth Schedule provides the interpretation of finance as follows: -

7. Finance, including-

(a) currency, legal tender and coinage;

(b) national savings and savings banks;

(c) borrowing on the security of the Federal Consolidated Fund; 
(d) loans to or borrowing by the States, public authorities and private enterprise;

(e) public debt of the Federation;

(f) financial and accounting procedure, including procedure for the collection, custody and payment of the public moneys of the Federation and of the States, and the purchase, custody and disposal of public property other than land of the Federation and of the States;

(g) audit and accounts of the Federation and the States and other public authorities;

(h) taxes; rates in the federal capital;

(i) fees in respect of any of the matters in the Federal List or dealt with by federal law;

(j) banking; moneylending; pawnbrokers; control of credit;

(k) bills of exchange, cheques, promissory notes and other similar instruments;

(l) foreign exchange; and

(m) capital issues; stock and commodity exchanges.

Based on the above statutory provisions, the following observations are made:

1) The term "gift" is specifically meant for hibah, which is related to the Muslim family law and therefore comes under the jurisdiction of Shari'ah Court except otherwise stated under the Federal List. The provision containing the term 'gift' is considered as a form of hibah, and as such it becomes a part of state matters, which is within the purview of Islamic administration under every state, hence under the jurisdiction of the Shari' ah Court $^{10}$;

2) the provision listed under the State List, where the Shari'ah Court has its jurisdiction over the dispute, will only be applicable for those professing the religion of Islam; Hence, should any of the disputed parties be non-Muslim, the civil court will automatically have the right to hear over the dispute;

3) the civil court will have an exclusive jurisdiction over matters pertaining to all sorts of contracts or agreements, but excluding the

${ }^{10}$ Muda, Mohd Zamro, "Instrument of Hibah and Wills: Analysis of The Regulations and Applications in Malaysia." Hibah and Faraid National Convention 2008, $\quad$ pp 1-42. http://www.islam .gov.my/sites/default/files/instruments of hibah and wills.pdf. 
hibah contract which will be under the Shari'ah scope of jurisdiction (this provision creates uncertainty on the position of hibah as a financial contract);

4) the term 'contract' as well as the interpretation of 'finance' stated in the Federal List are all within the activities of Islamic banks and financial institutions; thus, the civil courts will have the jurisdiction to hear disputes in respect of financial transactions, including hibah as financial instrument, instead of the Shari'ah court.

Latifah Mat Zin v. Rosmawati Sharibun \& Anor ${ }^{11}$ was the landmark case highlighting the conflict of jurisdiction between the Shari'ah Court and civil court pertaining to the matter of hibah. In this case, the Federal Court judges dismissed the appeal made by the appellant and ruled that the law of hibah was within the Shari'ah Court's jurisdiction. Briefly, the case revolved around monies which were kept in a joint account between the deceased husband and his third wife (the appellant). The issue was whether the hibah money kept in that account will entitle the appellant to bring the case under the civil court. The dispute arose when the respondents, the daughters of the deceased from the second wife brought the matter into the court to file a petition for a Letter of Administration of the estate of the deceased, including the monies kept in the respective joint account. The appellant in this case argued that the monies were granted to her by way of hibah or gift inter vivos, and thus it did not become part of the deceased's estate. The High Court who initially heard the case, decided that the applied law should be the Islamic law of hibah for the determination of that issue. However, in this case, the Court found that no hibah was made at that period of time. Therefore, the appellant appealed to the Court of Appeal, and stated that the judges in the High Court were wrong in deciding that matter with respect to the Islamic law of hibah, the law that should be applied is the civil law of banking or contract; or the law of probate and administration.

The Court of Appeal reversed the decision made by High Court as the disputed matter should be under Islamic law and of the view that the High Court has no jurisdiction to attend the case by virtue of Article

11 [2007] 5 CLJ 253, A Federal Court case, Putrajaya (The Judges are Abdul Hamid Mohamad, FCJ; Ariffin Zakaria, FCJ; Augustine Paul, FCJ) Civil Appeal No: 02-39-2006(W) 25 July 2007. 
121A of the Federal Constitution. Due to that reason, the Court of Appeal dismissed the appeal and set aside the order of the High Court even though the proof of hibah in the said joint account was found. Unsatisfied with the decision of the Court of Appeal, the appellant made another appeal to the Federal Court with the hope that the court will take into consideration the case of Jumaaton Awang \& Satu Lagi lwn. Raja Hizaruddin Nong Chik ${ }^{12}$, where the judges under this case decided that the case was under the law of probate and the administration, and therefore out of the jurisdiction of Shari'ah Court. The Federal Court judges in Latifah's case refused to accept the precedent made by the judges in Jumaaton case, dismissed the appeal, and were of the view that in the said case it was wrong to consider the issue as a whole since based on the findings of the case, there were still some issues which came within the matters of Shari'ah Court.

Based on the above cases, it was observed that the Shari'ah Court will have an exclusive jurisdiction over the matters of Islamic law, while the civil courts will have no right to interfere over the jurisdiction. However, the conflict of jurisdiction may still occur when the disputed matter appears to be in between two laws applicable; one on the side of Islamic family-related law and another on the side of Islamic law of contract in banking transaction, or under the law of probate and administration.

\section{THE UNCERTAINTY TERM BETWEEN HIBAH AND 'GIFT'}

The application of hibah in the Islamic deposit contract has been recognized by virtue of Section 148(a) of the IFSA. It indicates that hibah as widely known under IFSA is not limited to the takaful product only ${ }^{13}$.

Section 2 of IFSA has included "gift" as part of the definition for 'return'. Moreover, it was also brought forward under the definition of

12 [2004] CLJ (SYA) 100.

13 Umar A.Oseni, Dr. Noor Suhaida Kasri, "The Application of Hibah in the Islamic Financial Services Industry in Malaysia : Towards a ShariahOriented Legal Framework", International Shari'ah Research Academy for Islamic Finance (ISRA), 2016; pp 1-43. 
"investment account", "Islamic deposit", and "Islamic securities", Section 2 of IFSA provides the definition of return which includes gift:-

"return" in relation to the definitions of "financing facility", "investment account" and "Islamic deposit", and "Islamic securities" as defined in subsection 224(1), includes any form of rental, profit, dividend or benefit, and any fee or gift, payable or to be given;

Further, Section 148 (a) of IFSA provides the meaning of Islamic deposit, which also includes gift: -

148. For the purposes of sections 149 and 150, "Islamic deposit" means a sum of money or any precious metal or precious stone, or any article or thing as may be prescribed by the Minister, on the recommendation of the Bank, accepted, paid or delivered, in accordance with Shari'ah-

(a) on terms under which it will be repaid or returned in full, regardless whether the repayment or return is by way of instalments, with or without any gains, any form of rental, profit, dividend or benefit, including any fee or gift, payable or to be given, or any other consideration in money or money's worth, either on demand or at a time or in circumstances agreed by or on behalf of the person making the payment or delivery and the person accepting it;

Based on the above provision, the giving of return in the form of gift for Islamic deposit is permitted by law under IFSA. However, the legal term used is "gift" instead of hibah, even though one may argue that the gift indirectly means hibah. In this context, based on the abovementioned Section 2 and Section 148 (a), IFSA certainly recognizes hibah for banking products, but the term used for the purpose of Islamic deposit is 'gift' rather than $h i b a h^{14}$. The purpose of using the term 'gift' rather than the term 'hibah' directly is possibly because for easy differentiation between the term uses for Islamic deposit, and the term uses for the takaful product ${ }^{15}$. Most importantly, one should acknowledge that the granting of return for Islamic deposit

14 Umar A.Oseni, Dr. Noor Suhaida Kasri, "The Application of Hibah in the Islamic Financial Services Industry in Malaysia : Towards a ShariahOriented Legal Framework", International Shari'ah Research Academy for Islamic Finance (ISRA), 2016; pp 1-43.

15 Oseni and Kasri, "The Application of Hibah", 26. 
in the form of gift is allowed by virtue of Section 2 and 148(a) of IFSA. At present, this study suggests that instead of gift, the term ' $h i b a h$ ' is rather extensively applied for giving of are turn in relation to the money deposited by the customers under Islamic accounts.

Moreover, the term 'hibah' itself is already governed under the BNM Hibah Policy document, especially for qard deposit account. As such, the definition of what is considered a gift, under the definition of "return" in Section 2 and 148(a) of IFSA, is obviously uncertain and therefore subject to further interpretation, whether it also includes the term 'hibah' or not. It is further argued that the definitions of "investment account" and "Islamic deposit" under Section 2 have some implications in the application of discretionary unilateral hibah, in which it is normally non-contractual in Islamic banking products ${ }^{16}$. Further discussion towards this argument is not highlighted in details by the author, and thus needs further research and study.

\section{THE GIVING OF CONDITIONAL HIBAH IN TAKAFUL NOMINATION}

Presently, the concept of the conditional hibah in takaful industry in Malaysia is preserved by virtue of Section 142, Schedule 10, Para 3(2) of the Islamic Financial Services Act 2013 ("IFSA"). The provision is made in relation to the SAC-BNM Resolution in 2003 on the permissibility of the conditional hibah in takaful business. IFSA is the first specific framework in Malaysian legal history that gives special treatment of gifts associated with takaful benefits made under the Family Takaful and Personal Accident Takaful Certificates ${ }^{17}$. The introduction of this statutory provision gives a major impact and confidence to the takaful company to offer an option of conditional hibah to the beneficiary in respect of the nomination of name made by the takaful participant as it has been enforced under one standard law and regulation i.e the IFSA.

The giving of hibah on conditional term in takaful is subjected to the occurrence of an event, i.e. the death of the takaful participant, in order to be fully enforceable in transferring the ownership of the takaful

16 Oseni and Kasri, "The Application of Hibah", 26.

17 Oseni and Kasri, "The Application of Hibah", 26. 
benefit to the beneficiary. This becomes a controversial issue among Muslim jurists in terms of its conditions that is imposed between the hibah provider and the hibah recipient. Considering that this issue is still argued among Muslim jurists, the IFSA provision was introduced to legalize the conditional hibah contract in takaful products and services, which depends on the demise of the takaful participant. The conditional hibah in takaful, or also known as the hibah takaful, is only applied for the Family Takaful and Personal Accident Takaful Certificate only. For this purpose, the policy document on hibah issued by BNM which came into force on $31^{\text {st }}$ July 2018 also affirmed the permissibility of the conditional hibah upon the demise of the donor only for the takaful product.

Notwithstanding that the practice of conditional hibah in takaful for Muslim is permissible by law, it is still confronted with controversy. It has been argued that due to the absence of the statutory requirement of relationship status under the Paragraph 2 (1), and also in any other paragraphs of Schedule 10 IFSA, there is a possibility that the nomination made by the takaful participant especially as a beneficiary under the conditional hibah may be misused in cases where the takaful participant may decide to name any person (out of the family members) to receive the payment of the takaful benefits since there is no restriction imposed under Section 142 Schedule 10 IFSA $^{18}$.

Meanwhile, there are opinions that propose that the conditional hibah contract, as allowed under the IFSA, may be possibly misused by the takaful participant to deny the rights and benefits of the lawful heirs since the Act does not interpret clearly the meaning of the beneficiary referred to under the conditional hibah, nor does it have a specific provision that states the beneficiary must be someone who have coverable rights under the takaful against the takaful participant ${ }^{19}$;

18 Alias Bin Azhar, Mohammad Azam Hussain, Muhammad Hafiz Badarulzaman, Fauziah Mohd Noor, "Hibah Komersial : Satu Tinjauan Terhadap Prosedur dan Amalan di Malaysia (Commercial Gifts (Hibah): An Overview of the Procedure and Practice in Malaysia": In Seminar Waqf Iqlimi 2014 USIM, pp 542-552.

19 Rusni Hasan, Safinar Salleh, "Pematuhan Syariah Dalam Operasi Takaful di Bawah Akta Perkhidmatan Kewangan Islam (APKI) 2013 (Shariah Compliance of the Operation of Takaful under the Islamic Financial Services Act 2013)" 2017, Jurnal Syariah 25 (2): pp 247-266. 
this Act creates full authority for the takaful participant to name any individual as he or she wishes.

\section{THE CONTRACT OF HIBAH IN THE CONTEXT OF SECTION 26 OF THE CONTRACT ACT 1950}

The wider usage of hibah as a financial instrument in Malaysia will always be subjected to the central regulation as ordered by virtue of Article 74, 77 of Item 7, List I- Federal List of the Federal Constitution. Among the principal regulations that will be applied and referred is the Contract Act 1950.

In the case of hibah contract, one may find that there is a conflict of jurisdiction between the Shari'ah law and the Contract Act 1950. Section 26 of the Contract Act 1950 provides that an agreement made without consideration is void (except under three limited circumstances as stated under Section 26 i.e. it is in writing and registered; or is a promise to compensate for something done; or is a promise to pay a debt barred by limitation law). Under the Act, any agreement in general must have an exchange towards each other, and therefore cannot be made one-sided. Since hibah is a transfer of asset without consideration, it appears to fall exactly within Section 26. Thus, the extent of the enforceability of hibah-based instruments in Malaysia can be seen to be in contradicting with the Contract Act $1950{ }^{20}$. One of the exceptions to the general rule that may be related to hibah falls under sub-section (a) to Section 26 of the Contract Act 1950. Briefly, the provision of Section 26 provides: -

\section{Agreement without consideration, void, unless-}

26. An agreement made without consideration is void, unless-

it is in writing and registered

(a) it is expressed in writing and registered under the law (if any) for the time being in force for the registration of such documents, and is

${ }^{20}$ Abdullah Abdul Rahman, "Hibah : Recent Malaysian Shariah resolutions and its enforceability", Islamic Finance News (IFN) written on $15^{\text {th }}$ October 2014 (Volume 11 Issue 41). He is currently a litigation partner specialized in Islamic banking and finance and dispute resolution with the law firm Messrs Chooi \& Company. 
made on account of natural love and affection between parties standing in a near relation to each other;

\section{or is a promise to compensate for something done}

(b) it is a promise to compensate, wholly or in part, a person who has already voluntarily done something for the promisor, or something which the promisor was legally compellable to do; or

\section{or is a promise to pay a debt barred by limitation law}

(c) it is a promise, made in writing and signed by the person to be charged therewith, or by his agent generally or specially authorized in that behalf, to pay wholly or in part a debt of which the creditor might have enforced payment but for the law for the limitation of suits.

In any of these cases, such an agreement is a contract.

Explanation 1-Nothing in this section shall affect the validity, as between the donor and donee, of any gift actually made.

Explanation 2-An agreement to which the consent of the promisor is freely given is not void merely because the consideration is inadequate; but the inadequacy of the consideration may be taken into account by the court in determining the question whether the consent of the promisor was freely given.

Based on the above, it can be explained that the whole content of Section 26 and its Explanations are existent due to a number of English law precedents. Generally, under the English law, a promise, in order to be valid and binding between the parties, must have a consideration $^{21}$. In events where there is no consideration, that promise has to be confined in a deed or agreement. Failure to have these two (2) elements, i.e. consideration or that a promise has to be prescribed in a deed, will cause the promise made become unenforceable and invalid. It is further analysed that Section 26 does not affect the validity of the hibah since its nature and features are identical as gift under the common law. Explanation 1 of Section 26, as above, states the creation and validity of gift, whereby it does not provide a special indication as to what type of gift has to be created in order to be valid and acceptable

21 Umar A.Oseni, Dr. Noor Suhaida Kasri, "The Application of Hibah in the Islamic Financial Services Industry in Malaysia : Towards a ShariahOriented Legal Framework", International Shari'ah Research Academy for Islamic Finance (ISRA), 2016; pp 1-43. 
by law. Thus, there is no differentiation between the absolute gift, which will take effect immediately upon the execution of its deed or agreement, or the conditional gift, which will only take effect upon the happening of a certain event.

Additionally, the issue arises when one may find that the Section 26 (a) also provides the term ....between parties standing in a near relation to each other. In this circumstance, since the word "near relation' is not defined clearly under the Act, except what is mention in illustration (b) it has created an uncertainty as to whether it constitutes immediate family member or also covers people outside the immediate family ${ }^{22}$. Illustration (b) under the Act provides only the relationship between the father and the son, and this has resulted in a limited interpretation to be applied for hibah. In the case of Re Tan Soh $\mathrm{Sim}^{23}$, the court attempted to define the term "near relation". The party raised the issue of whether the agreement was made on a basis of natural love and affection, and whether the three sisters and seven halfsisters and brothers stood in near relationship to their adopted nephews and nieces. The court decided that the term 'relationship' must be applied and interpreted in each case according to the mores of the group to which the parties belong, and the court must also take into account the circumstances of the family concerned. In this case, the court held that the uncles and aunties of the adoptive mother did not really stand nearly to their nephews and nieces.

Section 26 (a) has further been measured in the case of Queck Poh Guan (as administrator of the estate of Sit Kim Boo, deceased) vs. Quick Awang ${ }^{24}$ over the issue of whether the instrument of transfer in favour of the defendant was void for non-compliance with Section 26(a). The judge under this case acknowledged the principle of natural love and affection and near relation, and held that the transfer of land by way of gift is valid since the defendant was a deceased's son. Hence, based on the two court cases, it is observed that in deciding the dispute over the gift matter, majority of the judges choose to narrow down the interpretation of near relation exclusively for the family members only,

22 Wan Kamal Mujani, Wan Mohd Hirwani Wan Hussain, Noor Inayah Yaakub, Rusnadewi Abdul Rashid, "The Concept of Law of Gift Inter Vivos Under Islamic Law and the Contracts Act, 1950", International Business Management 5 (6), 2011, pp 319-325.

23 (1951), MLJ 2.

24 (1998) 3 MLJ 388. 
even though there are many cases whereby the parties are not relative or have relationship within the meaning of the $1 \mathrm{aw}^{25}$.

However, Hibah contract however, under the Islamic law, is not restricted to be given to those who have near relations only; it can be arranged for any parties the donor intends to give to on his or her own discretion. Thus, it shows that the granting of gift under the civil law and the granting of hibah under the Shari'ah law is different in terms of the recipient of the gift (hibah) itself.

\section{THE HYBRID CONTRACT OF HIBAH AND TRUST AS A FINANCIAL INSTRUMENT}

Hibah amanah or hibah trust instrument became a new trend as the Islamic banking services offer a flexible and a guaranteed management of the hibah asset together with will making services.

In Malaysia, the hibah trust per se is not a banking product per se, but rather a trust product and service which is combined and said to be a with the Shari'ah compliant product. It onvolves a hibah contract offered by the authorized trustee company, such as Permodalan Nasional Berhad (PNB), Tabung Haji and Amanah Raya Berhad. It is observed that there are also few bankswhich has jointly collaborated with the trustee company in offering the hibah amanah services such as Bank Islam Malaysia Berhad with Amanah Raya Berhad (the Hibah Amanahraya document) and Bank Muamalat Malaysia Berhad with As-Salihin Trustee Berhad (Pri-Hibah or Hibah Declaration document).

A hibah amanah or hibah trust is a contemporary product that became popular especially for Muslims due to its flexible structure. Similar to the conditional hibah concept under the takaful business, the hibah amanah is undeniably another effort to overcome the issue of lengthy process in wealth estate planning among Muslims, as it is no longer a part of the estate of the deceased, which is subjected to the Muslim law of administration of estates. In the hibah amanah, the element of hibah and trust are structured together to meet the balanced

${ }^{25}$ Wan Kamal Mujani, Wan Mohd Hirwani Wan Hussain, Noor Inayah Yaakub, Rusnadewi Abdul Rashid, "The Concept of Law of Gift Inter Vivos Under Islamic Law and the Contracts Act, 1950", International Business Management 5 (6), 2011, pp 319-325. 
needs against the benefit from the hibah asset between the donor during his life and the donee after the death of the donor.

Although in practical it may seem legally undisputable between the parties involved, it was observed that there are some overriding Shari' $a$ h and legal issues, which needs to be addressed through a more detailed discussion and research.

In Islam, the hibah amanah concept is formed for the benefit of those who are still minor and have not yet attain the age of majority, or those who are mentally incapable by law, and therefore they may not be able to manage the asset ${ }^{26}$. In granting the hibah to the underage families for example, the trust would normally be given to the nearest family members, such as the father or the mother as the trustee, and the trustee will then be responsible to manage the minor hibah asset until he attains the age of majority by law. In the context of the law in Malaysia, someone has to reach the age of at least 18 years old to own the asset independently, and therefore the trustee is required to manage the asset prior to the age of majority as prescribed under Section 2 of the Age of Majority Act 1971.

In contrast to the Shariah practice, it is observed that the application and concept of hibah cum amanah in Malaysia has been modified from its original concept to suit its purpose as a financial instrument. Under the new concept of hibah trust, the donor can appoint any trustee to manage the hibah asset pending its delivery, even though the recipient is legally sound, has attained the age of maturity and thus has the ability to manage the asset on his own. The main difference between the direct hibah and hibah trust or amanah is that, the direct hibah involves direct transfer the ownership, as it will be automatically transferred to the donee. The hibah trust or amanah on the other hand, although the asset has already been transferred to the donee. The hibah thrust or amanah on the other hand, although the asset has already been transferred to the beneficiaries either legally or beneficially, the hibah donor can still enjoy the benefits of the hibah

${ }^{26}$ Mustofa al-Khin, Mustofa al-Bugho and Ali- al-Syarbaji, "Al-Fiqh AlManhaji Kitab Fikah Mazhab Syafie (Solehan Ayub,Terj.), Kuala Lumpur, 2004, Pustaka Salam Sdn.Bhd.pp 1139. 
asset, provided that the written consent has been obtained from the beneficiaries. $^{27}$

On top of that, the conflict of legal jurisdiction may arise since hibah practice is originally subjected to Islamic law as clearly provided under Item 1, List II of the Ninth Schedule of Federal Constitution, whilst at the same time Section 46 (2) (b) (v) and (vi), the Administration of Islamic Law (Federal Territories) Act 1993 (Act 505), provides the matter of Syariah High Court jurisdiction pertaining to the matter of hibah.

In Malaysian situation, the practice of hibah amanah is merely a replication of the practice of living trust in conventional counterpart. In other words, when hibah amanah is similar to the living trust, therefore it is subjected to the civil law provision. As a result, the civil law may have to be referred to in order to understand the concept of hibah amanah itself $^{28}$. Basically, the trust contract is governed under the civil law provision by virtue of Item 4 (e) (i) List I of the Ninth Schedule of Federal Constitution (Federal List) which provides the followings:

4. Civil and criminal law and procedure and the administration of justice,

(a) constitution and organization of all courts other than Syariah Courts;

(b) including-

(c) jurisdiction and powers of all such courts;

(d) remuneration and other privileges of the judges and officers presiding over such courts;

(e) persons entitled to practise before such courts;

${ }^{27}$ Nazrul Hazizi Noordin, Muhammad Issyam Ismail, Muhammad Abd Hadi Abd Rahman, Siti Nurah Haron, Adam Abdullah, "Re-evaluating the Practice of Hibah Trust in Malaysia" 2016, Humanomics 32 (4). Emerald Group Publishing Ltd Vol. 32 Issue: 4, pp.418-436, doi:10.1108/H-052016-0044.

${ }^{28}$ Akmal Hidayah Salim, Tajul Aris Ahmad Bustami, "Pelaksanaan Hibah Amanah Sebagai Suatu Instrumen Pengurusan Harta Islam di Malaysia (Execution of Hibah Amanah as an Instrument of Islamic Property Management in Malaysia)" 2017, KANUN Julai (2): pp 90-115, retrieved from content/uploads/2017/08/hibah.pdf.

http://jurnalkanun.dbp.my/wordpress/wp- 
(f) subject to paragraph (ii), the following:

(i) contract; partnership, agency and other special contracts; master and servant; inns and inn-keepers; actionable wrongs; property and its transfer and hypothecation, except land; bona vacantia; equity and trusts; marriage, divorce and legitimacy; married women's property and status; interpretation of federal law; negotiable instruments; statutory declarations; arbitration; mercantile law; registration of businesses and business names; age of majority; infants and minors; adoption; succession, testate and intestate; probate and letters of administration; bankruptcy and insolvency; oaths and affirmations; limitation; reciprocal enforcement of judgments and orders; the law of evidence;

(ii) the matters mentioned in paragraph (i) do not include Islamic personal law relating to marriage, divorce, guardianship, maintenance, adoption, legitimacy, family law, gifts or succession, testate and intestate;

At the same time, Item 1, List II (State List) of the Ninth Schedule of the Federal Constitutions also provides the provision on the trust (amanah) that is applicable for those who are professing the religion of Islam and it is subject to the Shari'ah law. The provision provides that:-

1. Except with respect to the Federal territories of Kuala Lumpur, Labuan and Putrajaya, Islamic law and personal and family law of persons professing the religion of Islam, including the Islamic law relating to succession, testate and intestate, betrothal, marriage, divorce, dower, maintenance, adoption, legitimacy, guardianship, gifts, partitions and non-charitable trusts; wakafs and the definition and regulation of charitable and religious trusts, the appointment of trustees and the incorporation of persons in respect of Islamic religious and charitable endowments, institutions, trusts, charities and charitable institutions operating wholly within the State; Malay customs; Zakat, Fitrah and baitulmal or similar Islamic religious revenue; mosques or any Islamic public place of worship, creation and punishment of offences by persons professing the religion of Islam against precepts of that religion, except in regard to matters included in the Federal List; the constitution, organization and procedure of Syariah courts, which shall have jurisdiction only over persons professing the religion of Islam and in respect only of any of the matters included in this paragraph, but shall not have jurisdiction in respect of offences except in so far as conferred by federal law; the control of propagating doctrines and beliefs among persons professing 
the religion of Islam; the determination of matters of Islamic law and doctrine and Malay custom.

As a result of the above two provisions, one may question which court is competent to handle the disputed cases in respect of the Muslims trust as the trust matter is clearly stated in both provision ${ }^{29}$. Besides, in the contemporary practice, the nature of the hibah amanah itself also contributes to the conflict of jurisdiction since the hibah asset itself can be in the form of equity and trust; and that the recipient of the hibah amanah is not restricted to the Muslim recipient only.

In Malaysia, the case of TM Feroze Khan \& Ors v Meera Hussein TM Mohamed Mydin ${ }^{30}$ can be regarded as the court case that created a legal precedent over the issue of the hibah amanah. In this case, the judge decided that the law applicable for the trust in Malaysia is the civil law, regardless the party involved is Muslim or Non-Muslim. ${ }^{31}$

Moreover, since the trust contract is relatively governed by the civil law, the law of trust under civil law will be prevailed over the Shari'ah law should any disputes arise in the case of hibah trust. The law of trust that is currently applied in Malaysia is called the Trustee Act 1949 (Act 208). This was proved as the Federal Court judge, in the case of Wan Naimah vs Wan Mohamad Nawawi ${ }^{32}$ applied the law of trust and not the Islamic law to enforce the gift by an oral declaration of trust, even though it was related to the Muslim family law. On the other hand, one should notify and understand that by law, any instruments which were executed on the basis of trust will be subjected to the Trustee Act 1949,

29 Akmal Hidayah Salim, Tajul Aris Ahmad Bustami, "Pelaksanaan Hibah Amanah Sebagai Suatu Instrumen Pengurusan Harta Islam di Malaysia (Execution of Hibah Amanah as an Instrument of Islamic Property Management in Malaysia)" 2017, KANUN Julai (2): pp 90-115, retrieved from content/uploads/2017/08/hibah.pdf.

http://jurnalkanun.dbp.my/wordpress/wp-

30 (2006) 1 CLJ (SYA) 250 (Court of Appeal Malaysia Penang).

31 Akmal Hidayah Salim, Tajul Aris Ahmad Bustami, "Pelaksanaan Hibah Amanah Sebagai Suatu Instrumen Pengurusan Harta Islam di Malaysia (Execution of Hibah Amanah as an Instrument of Islamic Property Management in Malaysia)" 2017, KANUN Julai (2): pp 90-115, retrieved from http://jurnalkanun.dbp.my/wordpress/wpcontent/uploads/2017/08/hibah.pdf.

32 (1974) 1 MLJ 41. 
whether or not the party involved is a person or a company, a Muslim or a Non-Muslim.

As to date of this is written, it is important to note that the hibah amanah instrument has yet to be governed by any statutory provision like hibah in takaful, which is protected by virtue of the Section 142, Schedule 10 of the Islamic Financial Services Act 2013. Nothing also has been clearly described in respect of the hibah amanah contract under the BNM Hibah Policy document. The only permissibility on the hibah amanah contract is based on the resolution made by the Federal Territory Shari'ah Committee (Fatwa Council) in its $56^{\text {th }}$ meeting held on $5^{\text {th }}$ October 2000 with regards to the proposal of the management of hibah by Bumiputra-Commerce Trustee Berhad ${ }^{33}$. Hence, this has created a gap in the law which needs to be solved quickly.

\section{CONCLUSIONS AND RECOMMENDATIONS}

The application of hibah as a financial instrument in the Islamic banking and takaful products and services is well recognized and accepted by the law in Malaysia. Although in general, it can be understood that the hibah as a financial instrument will fall under the purview of the Federal law, it still creates confusion in respect of the applicable laws, due to its dual application as a commercial hibah and non-commercial hibah which may possibly occur at the same time and occasion. The main legal issues of the application of hibah is pertaining to the conflict of law and jurisdiction as to whether it should be challenged under the civil court or Shari'ah court. In term of definition, the uncertain definition of gift as provided under Section 148(a) of IFSA also constitutes whether it includes hibah. Generally, IFSA had recognized hibah for banking products, but the term used for the purpose of Islamic deposit is gift rather than hibah. This may happen as for easy differentiation between the term uses for Islamic deposit, and the term uses for the takaful product. Besides, the giving of hibah on conditional term in takaful also becomes a controversial issue

33 Akmal Hidayah Salim, Tajul Aris Ahmad Bustami, "Pelaksanaan Hibah Amanah Sebagai Suatu Instrumen Pengurusan Harta Islam di Malaysia (Execution of Hibah Amanah as an Instrument of Islamic Property Management in Malaysia)" 2017, KANUN Julai (2): pp 90-115, retrieved from content/uploads/2017/08/hibah.pdf.

http://jurnalkanun.dbp.my/wordpress/wp- 
among the Muslim jurists in terms of its conditions as imposed between the hibah provider and the hibah recipient.

The conditional hibah in takaful can only be enforced to the beneficiary subject to the occurrence of an event, i.e. the death of the takaful participant. The conditional hibah in takaful, even though it has been permitted by Shari'ah Resolutions as well as IFSA, may still face an issue in practice. Among others, on the absence of the statutory requirement of relationship status in which case the takaful participant may decide to name any person (out of the family members) to receive the payment of the takaful benefits since there is no restriction imposed under Section 142 Schedule 10 IFSA. Furthermore, by virtue of Section 26 of the Contract Act 1950, the hibah contract as practiced in Islam may possibly have a conflict to be enforced under the Act. The hibah which is generally known as a contract made without consideration, can be seen to be in contradicting with the Act. However, having hibah in writing and registered can make it becomes enforceable under the Contract Act 1950. The validity of hibah can be recognized under the Act since its nature and features are identical as gift under the common law. The word 'near relation' under Section 26 has not been defined clearly under the Act, which results to an uncertainty as to whether it constitutes near relation between the immediate family members only, or also covers people outside the family group members, since in Islam, the giving of hibah is open to everyone. Finally, the application of hibah trust in the financial industry has been modified from its original concept in Islam as it is no longer purposely formed only for the benefit of those who are still minor and have not yet attained the age of majority, or those who are mentally disordered by law. Under the hibah trust, the issue of which law to be applied will be challenged since the trust contract is relatively governed by the civil law with the effect of prevailing over the Shari'ah law should any disputes arise in the case of hibah trust. In practice, the nature and function of hibah trust itself which based on the living trust as in the conventional counterpart may cause the party to bring the matter under the civil law of trust. Moreover, the hibah trust is yet to be protected by neither Shari'ah Resolutions nor the statutory provision like hibah in takaful.

Having concluded the issues, this study proposes the following recommendations. Firstly, the application of hibah in different segments under each of the Islamic product and service must always 
be subject to the statutory approval from the SAC BNM prior to its offering in the financial market. This is the most important process to be met before allowing the respective product in the market, in order to prevent Shari'ah non-compliancy instruments. Secondly, there is an urgent need to re-evaluate the existing legislation which seems to be unsuitable with the Islamic principle. For example, the hibah trust that has a combination of trust elements in the contract. In doing so, an independent policy document should be prepared to guide the application of any type of hybrid contract of hibah. Thirdly, the need for further research to study the implementation of hibah as an Islamic financial instrument from the legal perspective. For that, the academics and researchers are urged to explore and analyse the concept and application of the commercial hibah in the context of the Shari'ah and legal perspectives. In addition, further research is also needed to provide legal clarity on the terms of hibah and gift. The terms hibah and gift should also be clearly distinguished and clarified under the BNM Policy Document of Hibah. This provides a solution for the uncertainty of the term 'gift' for return and Islamic Deposit under Section 2 and 148 of IFSA. 